\title{
Indonesian National Army During the Covid 19 Pandemic
}

\author{
Angling ${ }^{1}$, Megawati Barthos ${ }^{2}$ \\ \{angling.yunanto2@gmail.com ${ }^{1}$, megawati_barthos@borobudur.ac.id²\} \\ Universitas Borobudur, Jakarta, Indonesia ${ }^{1,2}$
}

\begin{abstract}
This paper describes the strategic role of the Indonesian National Army during the Covid 19 Pandemic crisis. By using normative juridical methods and using literature studies as data collection, it was found that the Indonesian National Army had a vital role in urgency during the Covid 19 Pandemic. This role was visible in the form of social security, support for The Main Tool of the Indonesian Armed Forces' Weapon System (Alusista), and medical treatment in the form of the deployment of medical personnel and assistance to health facilities.
\end{abstract}

Keywords: Health; Covid-19 Pandemic; Security; Indonesian National Army

\section{Introduction}

The Coronavirus pandemic that has spread since the start of 2020 is one of the difficult issues right now confronting the world. The huge spread of the pandemic with the expanding number of passings has made an emergency in different areas. In the midst of restricted assets possessed by a country, numerous states have chosen to include their military in managing the pandemic, including Indonesia.

Indonesia affirmed the primary positive instance of Covid Illness 2019 (Coronavirus) on Walk 2, 2020. Then, at that point, in its turn of events, it was recorded that until July 5, 2020, the quantity of positive instances of Coronavirus had reached 63,749, comprising of 31,473 patients under treatment, recuperated upwards of 29,105 individuals, and patients who passed on contacted 3,171 individuals. When seen from the improvement of the chart, the example of Coronavirus spreads in Indonesia is as yet expanding, and there are no indications of an inclining bend..[1]

The Coronavirus pandemic, which has turned into a worldwide wellbeing emergency, affects human wellbeing, yet in addition has a cascading type of influence on the financial, social, and security areas. The effect of the pandemic on the financial and social states of the local area can be seen from many individuals encountering cutbacks (PHK), the expanding number of jobless that then, at that point, prompts an expansion in neediness rates. Furthermore, the declining financial states of the local area have a cascading type of influence on the security area, for example, the expansion in crime percentages during the pandemic that compromises security and public request locally. Besides, the lockdown approaches executed by adjoining nations, for example, Malaysia prompted the illicit bringing home of Indonesian Transient Laborers (TKI) through the "rodent course." Bringing home that isn't joined by a 
severe screening measure can possibly build the transmission of Coronavirus at the place of appearance and in their old neighborhood.[2]

Given the heightening of the spread of Coronavirus in Indonesia and the different effects it causes, on April 13, 2020, President Joko Widodo gave Official Pronouncement (Kepres) No. 12 of 2020 concerning the Non-Catastrophic events The spread of Coronavirus Assurance as a public debacle. The issuance of the Official Pronouncement means that the public authority sees the Coronavirus pandemic as a truly non-military danger that requires exceptional dealing with, adhering to Law Number 23 of 2019. The public authority has put forth a few attempts to conquer the Coronavirus pandemic, beginning from framing a Team for the Speed increase of Taking care of Coronavirus in collaboration with a few related services/offices and neighborhood states. The Service of Guard (Kemhan) and the Indonesian Public Military (TNI) are the two protection organizations that are additionally partaking in endeavors to contain Coronavirus.[3]

In Indonesia, the involvement of the Indonesian National Armed Forces (TNI) in handling Covid-19 has been carried out since the beginning of the year, even before the government officially announced the first corona case in Indonesia. Until August 2020, the TNI has been deployed for various tasks at the central and regional levels. Some of the tasks in question, such as providing observation facilities in Natuna, building a hospital on Galang Island, evacuating affected Indonesian citizens abroad, distributing medical equipment, guarding access at the border, overseeing the implementation of Large-Scale Social Restrictions (PSBB) policies, to escorting the implementation of health protocols in the new normal. In addition to assisting in handling the implementation of government policies, the Indonesian National Armed Forces are also actively involved as part of the team structure of the Covid-19 Handling Task Force and the Covid-19 Handling Implementation Committee and National Economic Recovery. [4]

Apart from various critical warnings regarding the tendency to expand the military role, no literature discusses how the supervisory response to military involvement in handling Covid19 in Indonesia. It is interesting to review because the function of this supervisory actor can be at the forefront in encouraging proportional military involvement while avoiding the impact of militarization or other negative influences on the military reform process and democratization in Indonesia. In this context, the paper intended to discuss the dynamics of supervision from the House of Representatives (DPR) and civil society towards the involvement of the TNI in handling Covid-19. This paper focuses on the role of the TNI in dealing with COVID-19. The engagement of the military in this health crisis has been performed since the COVID-19 outbreak broke out in Indonesia, during the Large-Scale Social Restrictions (PSBB) period, until the implementation of the current new normal.

\section{Method}

This research is normative juridical research.[5] As normative juridical research, this research is a legal norms-based analysis. Therefore, the object being analyzed is legal norms, both in statutory regulations and regional regulations contained in existing documents.[6]

Literature studies are used as a data collection instrument, from books, journals, and articles related to the research topic. The data that has been collected is then analyzed using descriptive analysis and presented comprehensively. 


\section{Discussion}

In light of Law Number 3 of 2002 concerning Public Protection, the meaning of public guard are generally endeavors to shield the power of the express, the regional trustworthiness of the Unitary Condition of the Republic of Indonesia, and the security of the whole Country from dangers and aggravations to the honesty of the Country and State.[7] The public guard exertion is done by considering the elements of the dangers confronted. The advancement of the essential climate makes changes in the intricacy of dangers, both military dangers, and non-military dangers. Public safeguard capacities to acknowledge and shield the whole domain of the Unitary Condition of the Republic of Indonesia as a guard unit. Public safeguard is coordinated by the public authority and arranged right on time with the public protection framework by building and cultivating the capacity and prevention of the state and country in beating any dangers.

The state protection framework is a widespread safeguard framework that includes all residents, regions, and other public assets, and is arranged right on time by the public authority and is done in an aggregate, coordinated, coordinated, and nonstop way to maintain state power, regional respectability, and security. the entire country from all dangers. The widespread guard framework can be executed by assembling all components of public assets, including parts of public safeguard, like Principle Parts, Hold Parts, and Supporting Parts.

The primary part is the Indonesian Public Military which is fit to be utilized to do safeguard assignments. Hold parts are public assets that have been arranged to be sent through activation to extend and reinforce the qualities and capacities of the fundamental parts. In the mean time, the supporting parts are public assets that can be utilized to build the force and limit of the principle parts and save parts.[7]

As indicated by the World Wellbeing Association (WHO), there are five stages in managing illness flare-ups. To start with, the expectation stage is expecting the reappearance of new illness flare-ups or likely episodes by working with early identification and reaction. Second, early recognition in creatures and people. Third, the infection control stage is endeavored to be done at the underlying transmission stage. Fourth, control and alleviation stages during intensification. Fifth, kill the danger of spreading the sickness. Moreover, WHO likewise furnishes powerful coordination measures in managing sickness flare-ups. In the first place, coordination between partners, coordination on errands as well as on monetary and asset the board. It requires the development of a crisis activity focus or functional administrative center, different apparatuses that help hierarchical advancement and gatherings between partners, making documentation and a joint game plan, which is refreshed consistently following the improvement of illness episodes, so it tends to be known what mediations are required, and how the jobs and obligations of chiefs are appropriated.Second, make health information containing disease outbreak surveillance and information on the results and impacts of interventions or policies that have been carried out. Third, dealing with the infodemic, namely the massive and rapid dissemination of information which includes false reports, rumors, gossip, and other unaccountable information. Policymakers must pass on official information and listen to and manage news properly to deal with the infodemic. Fourth, to conduct interventions in the health sector purposed to reduce transmission, morbidity, mortality, and negative influences on the health system and the political sector as other sectors.[8]

The legitimate premise that directs the association of protection organizations in assisting with speeding up the treatment of the Coronavirus pandemic is contained in Law no. 34 of 2004 concerning the Indonesian Public Military. Article 7 Passage 2 of the law expresses that one of the primary assignments of the Indonesian Public Military is to complete OMSP, which 
for this situation expects to assist adapt to the outcomes of catastrophic events, removal, and the arrangement of compassionate help. What's more, Official Guidance No. 4 of 2019 concerning limit working in forestalling, recognizing, and reacting to sickness flare-ups, worldwide pandemics, and atomic, natural, and synthetic crises is additionally the legitimate reason for allocating the TNI to help the public authority in conquering this worldwide wellbeing emergency.

The TNI Administrator is likewise trained to (a) send faculty, offices, and framework just as endeavors to forestall, recognize, and react rapidly previously, during, and after general wellbeing crises and additionally non-catastrophic events; and (b) giving strategic reaction orders in case of general wellbeing crises or potentially non-catastrophic events, if purposeful.[9] In the guideline, the president additionally offers directions to the Pastor of Protection to further develop coordination, collaboration, and participation in the preparation of safeguard area assets to forestall, distinguish, and react to general wellbeing crises or potentially non-cataclysmic events, if purposeful.

The TNI is helping the public authority in following clinical insight like huge testing, forceful contact following, and following, and severe quarantine to stifle the spread of COVID19. 6th, as far as innovative work (Research and development), the TNI teams up with colleges to lead innovative work in making antibodies, serums, or medications that can avoid Coronavirus at the Tactical Wellbeing Lab. As far as coordinations, the TNI additionally helps the public authority in dispersing PPE to different districts. The appropriation of PPE means to assist with beating the restrictions of PPE for clinical staff who treat Coronavirus patients. TNI utilizes air transportation, for example, Hercules airplane to ship and convey PPE, particularly to regions.

The involvement of the TNI has also expanded in subsequent developments. When the government implemented Large-Scale Social Restrictions (PSBB) in April-May 2020, the TNI was deployed to provide medical support (personnel, facilities, logistics, public kitchens, etc.), outreach to the public, spraying disinfectants, coordinating volunteers, collecting and distributing logistics to assisting security activities and implementing PSBB policies in the community. After the PSBB was terminated (June-August 2020), the government implemented a new normality protocol and focused on improving the economy. Instead of reducing the proportion of involvement as an implication of easing PSBB, in this new normal situation, the government has deployed 150,000 TNI soldiers to help discipline residents in implementing new health protocols.[8]

In the security sector, the Indonesian National Armed Forces leadership has established four Integrated Joint Task Forces (Kogasgabpad) in four regions. The formation of Kogasgabpad also involved elements of the combined TNI-Polri, relevant ministries, and institutions under the Indonesian National Armed Forces' primary operations command (pangkotama ops). The four Kogasgabpad consist of the first, the Wisma Atlet Jakarta COVID-19 Emergency Hospital, which is led by the Pangdam Jaya. Second, Kogasgabpad Natuna led by Pangkoopsau I. Third, Kogasgabpad Pulau Sebaru led by Pangkoarmada I. Fourth, Kogasgabpad Special Hospital for Galang Island Infection led by Pangdam 1 Bukit Barisan.

Moreover, the TNI additionally gives socialization in the utilization of veils and physical removing applications openly places like public transportation. To authorize and direct the organized execution of the PSBB and the momentary stage, the TNI completes joint watches out in the open places up to provincial lines. For instance, the Naval force held an Activity to Authorize Request and Discipline (Gaktibplin) meant to stifle petty criminal offenses for staff and government workers (PNS). 
Then again, as a preventive measure, the TNI has additionally pre-arranged an emergency course of action as a most dire outcome imaginable if the Coronavirus pandemic has not given any indications of dialing back quickly. The spread of the Covid has affected the declining financial states of the local area, so there is the chance of social distress that keeps on prompting anarchic activity. Along these lines, this alternate course of action is ready to decrease social turmoil that happens locally, to limit security chances.

To limit the effect of the Coronavirus pandemic and PSBB in the financial field, particularly for the lower working class, the TNI is playing a functioning job in appropriating food gifts and social help to individuals out of luck. What's more, the TNI is additionally working with the Public Police to assemble public kitchens in a few areas, remembering for Kota Tua, Tamansari, Tanjung Priok, South Tambun, Kemayoran, and two regions in South Jakarta. TNI-Polri officials alternate preparing to serve nourishment for inhabitants like consultants, online bike cabbies, and others.

As another model, the Indonesian Armed force is working with the Service of Agribusiness to make rice ATMs to help occupants during this pandemic. As an underlying stage, this program has just been carried out in 10 Military Area Orders (Kodim) that later on, it intended to cover all Kodim. This program plans for occupants influenced by Coronavirus who are not enrolled as recipients of help from the public authority.[10]

\section{Conclusion}

The fundamental parts and backing for protection have been associated with aiding the public authority adapt to the Coronavirus pandemic. The TNI has assumed a part at the functional level in dealing with Coronavirus locally, including the wellbeing, security, and socio-financial matters fields. By and large, the inclusion of the TNI in endeavors to manage Coronavirus enjoys a few benefits, like the preparation and sharpness of the warriors, since they are prepared to be prepared to confront different conditions and circumstances, including during emergency conditions like today. What's more, the current order framework in the TNI can work with the assembly of officers in assorted regions to do tasks. The TNI additionally has a vital and extensive arrangement so its execution can be done viably and in an incorporated way.

\section{References}

[1] A. K. Dewanti, "Darurat PHK di Tengah Corona," Arsip Publ. Ilm. Biro Adm. Akad., 2020.

[2] R. A. M. dan R. N. Nurwati, "Dampak pandemi covid-19 terhadap peningkatan angka pengangguran di indonesia," Kesejaht. Sos., 2020.

[3] P. S. Saraswati, "Kebijakan Hukum Terhadap Penanganan Pandemi Covid-19 di Indonesia," KERTHA WICAKSANA, vol. 14, no. 2, pp. 147-152, Jul. 2020, doi: 10.22225/kw.14.2.1923.147-152.

[4] E. A. Laksamana and R. Taufika, "How 'Militarized' is Indonesia's Covid-19 Management? Preliminary Assessment and Findings.” CSIS Commentaries, DMRU075-EN, 2020.

[5] J. Ibrahim, "Teori dan Metode Penelitian Hukum Normatif," Bayu Media, Malang, 2006. 
[6] M. H. Dr. johnny ibrahim,SH., Teori \& Metodologi Penelitian Hukum Normatif. 2006.

[7] "Law of the Republic of Indonesia Number 34 of 2004 concerning the Indonesian National Army.” .

[8] J. Honna, "Military Politics in Pandemic Indonesia," Asia-Pacific J., vol. 18, no. 5, 2020.

[9] " Instruction of the President of the Republic of Indonesia Number 4 of 2019 concerning Capacity Building in Preventing, Detecting, and Responding to Disease Outbreaks, Global Pandemics, and Nuclear, Biological, and Chemical Emergencies." .

[10] S. A. Taufan, " Helping Residents Affected by Covid-19, TNI AD Launches Rice ATM Program," https://www.jawapos.com/nasional/30/04/2020/ bantu-wargaterdampak-covid-19-tni-adluncurkan-program-atm-beras/, 2020. https://www.jawapos.com/nasional/30/04/2020/\%0Abantu-warga-terdampak-covid-19tni-adluncurkan-program-atm-beras/ (accessed Aug. 20, 2021). 